Review

\title{
Genetic and Molecular Control of Somatic Embryogenesis
}

\author{
Camille Salaün, Loïc Lepiniec (D) and Bertrand Dubreucq *(D) \\ Institut Jean-Pierre Bourgin, INRAE, AgroParisTech, Université Paris-Saclay, 78000 Versailles, France; \\ camille.salaun@inrae.fr (C.S.); loic.lepiniec@inrae.fr (L.L.) \\ * Correspondence: bertrand.dubreucq@inrae.fr
}

Citation: Salaün, C.; Lepiniec, L.; Dubreucq, B. Genetic and Molecular Control of Somatic Embryogenesis. Plants 2021, 10, 1467. https:// doi.org/10.3390/plants10071467

Academic Editors: Paloma Moncaleán and Itziar A. Montalbán

Received: 25 June 2021

Accepted: 13 July 2021

Published: 17 July 2021

Publisher's Note: MDPI stays neutral with regard to jurisdictional claims in published maps and institutional affiliations.

Copyright: (c) 2021 by the authors. Licensee MDPI, Basel, Switzerland. This article is an open access article distributed under the terms and conditions of the Creative Commons Attribution (CC BY) license (https:// creativecommons.org/licenses/by/ $4.0 /)$.

\begin{abstract}
Somatic embryogenesis is a method of asexual reproduction that can occur naturally in various plant species and is widely used for clonal propagation, transformation and regeneration of different crops. Somatic embryogenesis shares some developmental and physiological similarities with zygotic embryogenesis as it involves common actors of hormonal, transcriptional, developmental and epigenetic controls. Here, we provide an overview of the main signaling pathways involved in the induction and regulation of somatic embryogenesis with a focus on the master regulators of seed development, LEAFY COTYLEDON 1 and 2, ABSCISIC ACID INSENSITIVE 3 and FUSCA 3 transcription factors whose precise role during both zygotic and somatic embryogenesis remains to be fully elucidated.
\end{abstract}

Keywords: embryogenesis; LAFL; transcriptional regulation; epigenetic control

\section{Introduction}

Plants can propagate through sexual or asexual reproduction. In Angiosperms, zygotic or sexual reproduction is the most common and consists of the double fertilization of a female gametophyte (that contains the egg and the central cell) by the two sperm cells of a male gametophyte (pollen). Sexual reproduction leads to the formation of a seed that contains all the components required for seedling development: the differentiated zygotic embryo which will give rise to the future plant, storage compounds located in the cotyledons, endosperm and/or nucellus depending on the species, all surrounded by a protective tissue, the testa (formed by ovary integuments) [1]. Through meiosis and crosses, zygotic reproduction allows genetic diversity in the progeny and its propagation through seeds, that can be transported through wind, water (hydrochory) or animals (zoochory) [2]. However, plants are also able to reproduce in an asexual way, i.e., without meiosis and fertilization. For example, apomixis consists in the formation of a seed derived from a diploid cell of the ovule and can occur naturally in some species [3]. Vegetative reproduction is also widespread and used in horticulture, with different techniques such as layering, cuttings, and grafting.

This study focuses on somatic embryogenesis (SE), a complex process of clonal propagation by which plants can form embryos without meiosis and fertilization. This process involves the totipotency of plant cells, i.e., their ability for dedifferentiation and differentiation in new cellular types. The new plant derived from a somatic embryo is thus genetically identical to the mother plant. SE can occur spontaneously or in response to specific environmental conditions in some species such as Kalanchoe $[4,5]$.

Understanding the mechanisms controlling somatic embryogenesis and its regulation is a key issue in plant biology, since clonal propagation through SE is widely used for various plants of agronomic interest, such as Coffea spp. [6], Pinus spp. [7], Theobroma cacao L. [8] and other species, as it facilitates the clonal multiplication of elite genotypes in a quite fast and efficient way [9]. Moreover, SE is also largely used for genetic transformation protocols of these agronomical species, and for other crops such as rice, soybean, maize, or wheat [10-12]. Because the efficiency of transformation is correlated with the embryogenic and regeneration capacity, comprehension of SE processes is of great importance. 
However, somatic embryogenesis involves complex, or even not characterized, genetic inheritance [13]. Some species or specific genotypes can display a recalcitrance to SE and are unable to undergo it even under favorable conditions. Lastly, although somatic and zygotic embryogenesis (ZE) share some similar hormonal, transcriptional or epigenetic controls [14], they also display some specificities. In this review, the known regulatory mechanisms involved in SE and ZE are compared with a specific focus on the LAFL (LEC1, $A B I 3$, FUS3 and LEC2) gene regulatory network.

\section{Onset of Somatic Embryogenesis}

Somatic embryogenesis relies on the totipotency of plant cells, i.e., their capacity to dedifferentiate and differentiate in a new cell type $[15,16]$. Although some plant species such as Kalanchoe daigremontiana undergo spontaneous SE [4], this process is usually induced in vitro by a stress over the plant tissues. This stress, that is essential for SE induction, can take different forms (reviewed in [17]): a high level of plant hormones in the culture media is the most commonly used [18,19], but it also can be wounding, extreme $\mathrm{pH}$, osmotic or heat shock, or treatments with different chemicals. The first stages of SE are characterized by the induction of the expression of numerous stress-related genes and especially those encoding transcription factors belonging to AP2/ERF, MYB, AUX/IAA, B3 or WUS/WOX families [19-21].

Somatic embryos can be induced directly from in vitro cultivated plant tissues (for example immature zygotic embryos) on a low-auxin medium. Alternatively, indirect SE can be induced by cultivating embryogenic tissues, such as callus, on an auxin-rich medium leading to the transition to somatic embryos by switching to a low-auxin medium [22,23]. The protocols used for industrial clonal reproduction or for the research on somatic embryos are usually based on indirect SE, since it allows the production of a large number of somatic embryos [22-24] and because direct SE can be ineffective for some species or genotypes, such as Gossypium hirsutum [25], Capsicum chinense Jacq., or Cocos nucifera L. [26].

\section{Hormonal Control of Somatic Embryogenesis}

Multiple events in the plant life cycle, such as development or responses to biotic and abiotic stresses, are controlled or regulated by hormones. Auxins are known to play essential roles in all the aspects related to plant development, from cellular division to elongation, through cell identity and organogenesis [27,28]. Auxin polar transport by the proteins PIN (efflux) and AUX (influx) leads to differential distributions, with gradients and maxima that are essential for plant development [29]. During zygotic embryo development, local auxin production, polar transport and gradient are mainly mediated by PIN proteins [30]. More specifically, in Arabidopsis, the expression of PIN1 and PIN7 genes in the apical part of the young embryo is at the basis of the acquisition of the apical-basal orientation $[30,31]$, in concert with $A U X 1, L A X 1$ and $L A X 2$, playing a cooperative role [32].

Not surprisingly, auxin was thus shown to be a central player in the induction of $\mathrm{SE}$ as reviewed in [33]. Briefly, auxins and more specifically 2,4-dichlorophenoxyacetic acid (2, 4-D), a synthetic auxin-like plant growth regulator, are largely used for inducing SE [19]. The treatment of plant tissues with 2, 4-D involves both a stress and the auxin response, biosynthesis and signaling pathway, as well as a transcriptional reprogramming and chromatin remodeling (as described below) [33]. Similar to zygotic embryogenesis, a polar transport and auxin gradient are necessary for the formation of a somatic embryo [34]. SE induction, as well as organogenesis and plant regeneration, depends on the addition of plant growth regulators (PGR) such as auxins and cytokinins [18]. Although many protocols adapted to different species and genotypes are available, a key element for embryo formation is the large variation in PGR concentration added to the culture media [24]. A majority of protocols are based on the use of auxins, alone or combined with cytokinins [24]. During SE induction, auxin response factor $(A R F)$ genes display specific expressions being up- or down-regulated, suggesting that auxin signaling is central in the 
process [35]. Moreover, YUCCA and AUX/IAA genes that are respectively involved in auxin biosynthesis and response, are transcriptionally regulated during SE, including by LAFL transcription factors [36,37].

Growing plant tissues in vitro with high concentrations of auxin (2, 4-D), triggers a general reprogramming of somatic cell transcriptomes and modulates the expression of many SE-associated transcription factors [33]. Moreover, when protoplasts are cultured with a medium containing high concentrations of 2, 4-D, the size of their nuclei is significantly increased, suggesting a reorganization of the chromatin [38]. Finally, hormonal stress induces a modification of chromatin state, leading to the activation of transcription factors such as WUS, LEC genes or BBM that are specific to embryogenic programs [39]. These results suggest that hormones, especially auxin, trigger a general reprogramming of gene expression through chromatin modifications and activation of specific transcription factors.

\section{Transcriptional Control of Somatic Embryogenesis}

The main way to regulate gene expression is the transcriptional initiation through transcription factors (TF). Transcriptional regulation performs an essential role in somatic embryogenesis [40]. In Arabidopsis, the ectopic expression of some transcription factors, such as LEC genes, BBM, WUS /WOX genes or AGL15 can increase the efficiency of SE induction and lead to the formation of somatic embryos without adding hormones [23]. Mutations in these genes have a negative impact on the efficiency of SE induction [1,41,42]. Several of the TF are involved in hormonal signaling, while others control cellular differentiation and organogenesis. These transcription factors are described below.

\subsection{LAFL (LEC1, LEC2, ABI3, FUS3)}

ABSCISIC ACID INSENSITIVE 3 (ABI3), FUSCA 3 (FUS3) and LEAFY COTYLEDON 2 (LEC2) are transcription factors forming the AFL group. They belong to the plant-specific B3 family of transcription factors, characterized by a highly conserved B3 DNA binding domain of $~ 110$ amino-acid residues first characterized in ABI3/VP1 [43,44]. B3-containing factors can recognize specific target DNA with a 5'-GATC-3' core sequence, known as $R Y$ boxes and conserved within the promoters of storage genes $[45,46]$. Together with LEAFY COTYLEDON 1 (LEC1), a NF-YB transcription factor [1] involved in CAAT box complexes [47], AFL form the LAFL group of master regulators of seed development [48-50]. They can genetically and/or physically interact altogether and form protein complexes to activate their target genes [46,51] and control various aspects of seed development, such as the accumulation of storage compounds or the acquisition of desiccation tolerance (Figure 1). The expression of LAFL genes is regulated by transcription factors, such as BBM [52], hormonal signaling (ABA, GA, IAA) [53] and chromatin modifications [52].

These genes are involved in somatic embryogenesis programs as well as in the initiation and maintaining of the embryogenic fate of plant cells [54] (Figure 1). Indeed, the ectopic expression of $L E C$ genes (LEC1, LEC2, and FUS3) in Arabidopsis and in other species can induce the spontaneous formation of somatic embryos without addition of hormones in the culture medium [42,55-59]. The expression of GhLEC1, GhLEC2 and GhFUS3 is significantly higher in cotton (Gossypium hirsutum) genotypes permissive to callus differentiation, than in recalcitrant genotypes [60]. Consistent with this role, lec1, lec2 and fus 3 simple and multiple mutations severely impair the ability to form somatic embryos in Arabidopsis [60]. 


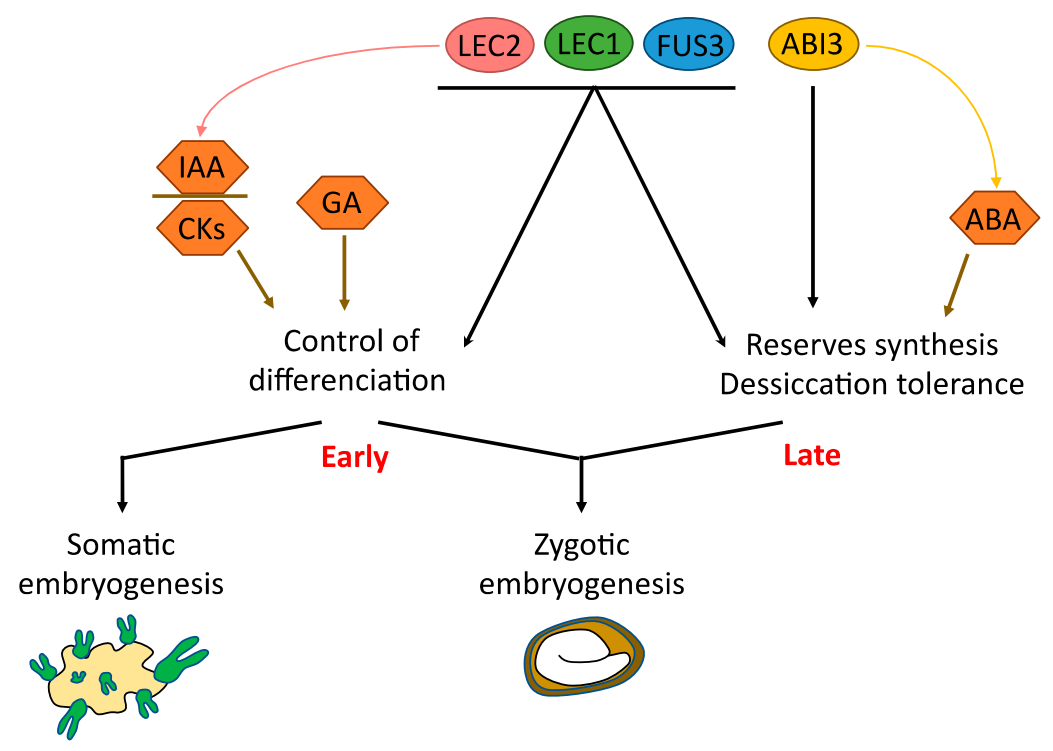

Figure 1. The roles of $L A F L$ genes in somatic embryogenesis (SE) and zygotic embryogenesis (ZE). IAA: auxins, CKs: cytokinins, GA: gibberellins.

Several target genes of the LEC proteins can be directly involved in the regulation of somatic embryogenesis [33,61], such as AGL15, that is involved in hormonal signaling and controls the embryogenic induction [62]; IAA30, a main actor of auxin signaling and perception [63] or $L O B 40$, a TF putatively involved in the formation of organ boundaries and gibberellins signaling [64]. LEC2 and AGL15 control each other in a feedback regulatory loop [33]. LEC2 is also known to rapidly induce the expression of auxin-related genes, such as IAA1, IAA17 and ACS4, and key enzymes involved in auxin biosynthesis such as the YUC genes (YUC1, YUC2, YUC4, YUC10) [37,65]. However, among these auxin genes, only YUC4 is a direct target of LEC2. Then, it can be hypothesized that LEC2 (and LEC1) can induce SE processes through different mechanisms (Figure 2). The LEC proteins activate the maturation program, leading to the increase in various storage compounds and the decrease in water content. These physiological changes would trigger a stress inducing SE competency and/or promotion of auxin activity in competent cells [65]. In addition, some genes usually expressed during zygotic embryo development and known to bring an embryogenic competence, such as AGL15 for example, are directly induced by LEC2 [65]. Another hypothesis can be a dual function of LEC2, able to act as a regulator of seed maturation by regulating specific targets in complex with specific partners, and as a regulator of embryogenesis (both ZE and SE), by regulating other targets, in cooperation with other partners (Figure 2).

ABI3 is involved in ABA-mediated developmental and metabolic processes, such as seed maturation, accumulation of seed proteins or the transition between embryo maturation and early seedling development [66]. ABI3 is essential for the emergence of roots from callus after induction of organogenesis. The abi3-6 mutant does not show any regeneration after passing from a hormone-rich to a hormone-free medium [67]. Nevertheless, the overexpression of $A B I 3$ does not induce somatic embryogenesis [68,69]. Because the expression of auxin-related genes is significantly weaker in the abi3-6 mutant, ABI3 can be involved in auxin distribution and/or homeostasis, with its role in ABA signal transduction and reserve accumulation, rather than in the initiation of SE as other LAFL.

Although very similar in their B3 sequences and binding capabilities [46], LAFL are thus involved to a different extent in somatic embryogenesis (Figures 1 and 2). This is consistent with their different DNA binding activities [46] and their specific expression patterns. 
A

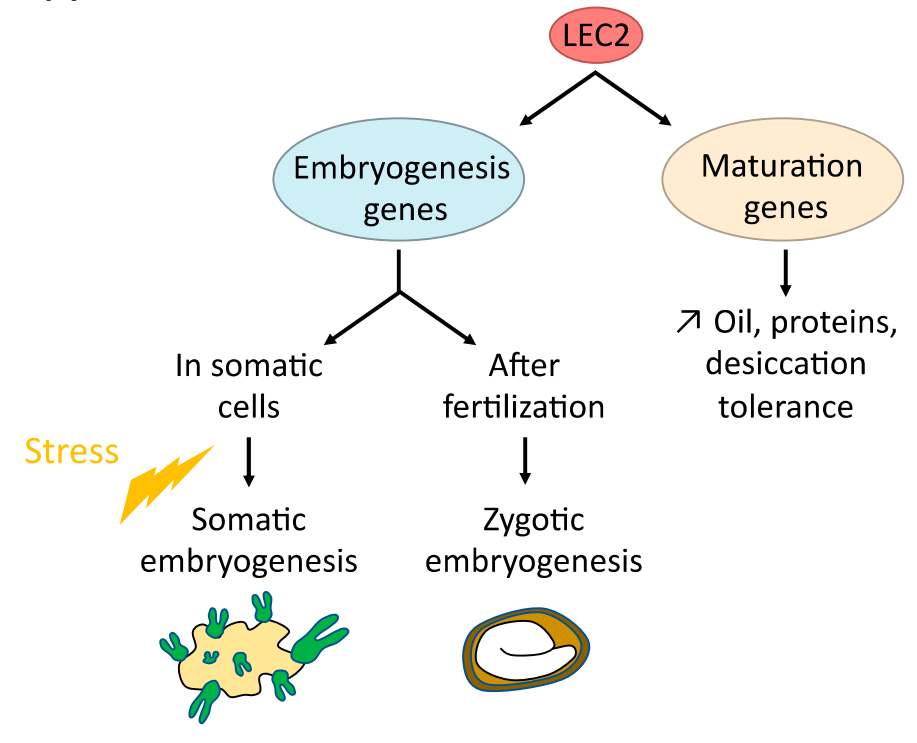

B

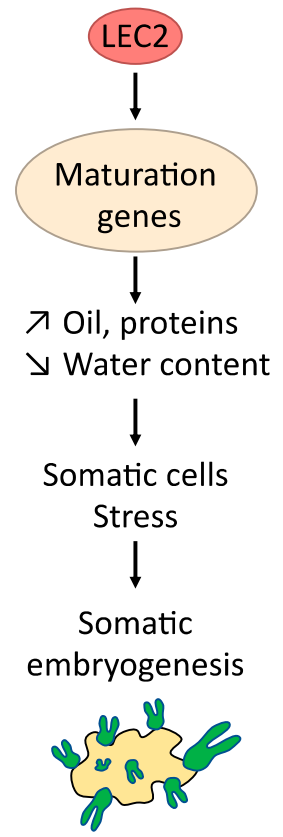

Figure 2. The possible roles of LEC2 in somatic embryogenesis. (A): LEC2 can have a dual function, one specific to embryogenesis, the other inducing maturation genes. The embryogenesis function may lead to SE or ZE depending on the type of cell it is expressed in, as well as possible stress and epigenetic modifications. (B): LEC2 induces stress through the accumulation of reserve specific compounds in the cells.

\section{2. $B A B Y B O O M(B B M)$}

BABY BOOM (BBM), also known as PLETHORA 4 (PLT4) is a transcription factor belonging to the AP2/ERF TF family characterized by a DNA binding domain of 70 aminoacid residues, that were first characterized in APETALA2 (AP2) and ethylene-responsive element binding proteins (EREBP) [70,71]. The AP2/ERF family is divided into two subfamilies: TFs that count one AP2/ERF DNA binding domain and are generally involved in response to abiotic and environmental stresses [72], and those counting two DNA binding domains, known to regulate developmental processes. BBM contains two AP2/ERF domains and is a member of the AINTEGUMENTA-LIKE (AIL) subfamily, composed of eight members, all carrying specific functions in the division of meristematic and embryonic cells and involved in the regulation of SE and its induction when they are ectopically expressed [33]. $B B M$ is expressed in the zygotic embryo and regulates cell identity and the growth of the root meristem [73]. The ectopic expression of BBM in Arabidopsis thaliana and Brassica napus leads to the spontaneous formation of somatic embryos and cotyledon-like structures over plantlets [70]. However, other phenotypes are also induced by ectopic expression of $B B M$ in these species, such as callus proliferation, ectopic shoot formation, alterations in leaf morphology and better regeneration of explants during in vitro culture, without adding hormones in the medium. BBM can thus have a stimulating role in cell proliferation and morphogenesis during both $\mathrm{SE}$ and $\mathrm{ZE}$. BBM directly binds promoter regions of $L A F L$ genes through its ANT/AIL binding motif and AGL15 via another motif or an intermediate protein [52]. $L A F L$ genes are upregulated after $B B M$ induction, and together with AGL15, are BBM-positive regulators during SE processes and are key components of the BBM signaling pathway, although these interactions may be indirect.

\subsection{WUSCHEL (WUS) and WUSCHEL-RELATED HOMEOBOX (WOX) Genes}

WUSCHEL (WUS) is a homeobox transcription factor that is described as a key regulator of meristematic stem cell fate [74]. It also performs an essential role in somatic embryogenesis, by promoting the vegetative-to-embryonic transition and the maintenance 
of embryogenic cell identity [75]. WUS is involved in the regulation of the embryogenic cell (totipotency) and meristematic cell (pluripotency) fates [76]. In Arabidopsis, wus mutants can form somatic embryos, although seedlings display the same phenotype as seed-derived wus plantlets, i.e., an absence of functional embryonic shoot apical meristem (SAM), and the typical wuschel stop-and-go development described in [74] consisting, among others, in the formation of new shoot meristems instead of organs at the primordia [77]. The overexpression of WUS and gain of function mutations can increase somatic embryo production or induce the formation of somatic embryos from vegetative tissues without addition of external hormones in Arabidopsis thaliana [75]. In many other species, such as Gossypium hirsutum [78] or Coffea canephora [79], the overexpression of WUS is also able to significantly increase the ability of a plant to form somatic embryos. In Gossypium hirsutum, the ectopic expression of AtWUS, increases the efficiency of callus differentiation of recalcitrant genotypes [60]. WUS can also be used as a marker gene of dedifferentiation after SE induction in Medicago truncatula [80]. During SE, WUS is upregulated and transcriptionally induces LEC1, LEC2, and AGL15 genes [76]. Thus, we can hypothesize that SE originates from a cellular reprogramming followed by a process similar to ZE, at least in the signaling cascade of some key genes. When some master genes of ZE are knockdown (including $L A F L), \mathrm{SE}$ is impaired, favoring such a hypothesis. Two fully independent pathways exist, yielding to similar developmental structures. This hypothesis can be tested by comparing SE efficiency of the double mutants (e.g., wus/lec2) or double ectopic expressions to the single mutations/ectopic expression.

The WUSCHEL-RELATED HOMEOBOX (WOX) genes share similar sequences with the WUS homeodomain and a specific WUS box located downstream of the homeodomain [81]. WOX genes are involved in the early embryonic patterning but also in different signaling pathways regulating several aspects of plant growth and induction of somatic embryogenesis [76]. Functions of the different known WOX genes in several species are reviewed in [76]. As an example, it was shown in Medicago truncatula, that MtWOX9-1 overexpression improves SE efficiency, linked to an increase in AGL15 and AGL8 level of accumulation [82] and WOX5 is significantly upregulated two days after SE induction and can serve, such as WUS, as a marker of dedifferentiation [80].

\subsection{AGAMOUS-LIKE 15 (AGL15)}

AGAMOUS-LIKE 15 (AGL15) is a transcription factor, belonging to the MADS domain protein family. These TFs are known to share a specific MADS DNA binding domain, containing a 55 to 60 amino-acid sequence conserved among eukaryotes [83]. AGL genes display diverse functions in plant development, more particularly in flower development, although AGL15 is mainly detected in developing embryos [84,85]. AGL15 can target and regulate the expression of numerous hormone-related genes, including gibberellic acid and ethylene metabolism but also auxin signaling via GA20x6 [86] and IAA30 activation [62,86]. AGL15 activates its own expression [87] and regulates LEC2, ABI3 and FUS3 in a positive feedback regulatory loop [36]. The ectopic expression of AGL15 in Arabidopsis thaliana and in soybean increases SE capacity $[88,89]$. While the efficiency of SE plant tissue can decrease with time, overexpression of AGL15 maintains SE capacity for years, showing the role of AGL15 in the preservation of embryogenic capability [88]. The loss-of-function of AGL15 reduces the frequency of somatic embryo development [89].

\subsection{WOUND INDUCED DEDIFFERENTIATION 1 (WIND1)}

WOUND INDUCED DIFFERENTIATION 1 (WIND1) is an AP2/ERF transcription factor with two AP2 domains involved in callus formation in response to wounding and performs a critical role in the acquisition of regeneration competency and regulating cytokinin signaling [90,91]. The over- and ectopic expression of WIND1 leads to the callus formation on explants without induction through the addition of hormones in the culture medium or wounding [91]. WIND1 is not directly involved in the induction of SE, but in the induction of callus formation and regeneration competency. However, the induction of 
WIND1 expression followed by that of LEC2 leads to the formation of callus within all the plant tissues that can be regenerated in a whole plant, showing that WIND1 acts upstream from LEC2 during SE and regeneration processes [92].

Through the example of several transcription factors, we have seen that transcriptional control performs a key role in the initiation and efficiency of somatic embryogenesis. Aside from their role in the transcriptional activation of their targets through the promoting regions, some eukaryotic TFs can activate their targets even if they are located in nucleosomal DNA that is less accessible. These specific TFs, called pioneer transcription factors, are usually submitted to strong (spatiotemporal) transcriptional or post-transcriptional controls and can act directly or indirectly by recruiting chromatin remodelers, thereby increasing local chromatin accessibility [93]. Pioneer factors are of primary importance in development since they allow the chromatin to be open and accessible for other factors to bind, and thus, are thought to enable cellular reprogramming [94]. This is the case for LEC1, that is a pioneer transcription factor capable of inducing chromatin modifications to different target genes: its overexpression leads to the spontaneous formation of somatic embryos on plantlets and its loss-of-function mutants are not able to do SE anymore [54,57,95-97].

\section{Epigenetic Regulation of Somatic Embryogenesis}

Although chromatin regulations are essential in developmental processes, relatively little data concerning the epigenetic regulation of somatic embryogenesis have been published (see [98] for review). DNA methylation profile and chromatin accessibility are constantly changing in response to cellular needs and environmental constraints [99]. The different abiotic stresses to which plants are subjected can either increase or reduce DNA methylation, depending on the type of stress (i.e., heavy metals, salt, temperature, culture density), the plant species or even the organ considered $[100,101]$. It should be noted that epigenetic changes induced can be transient or stable over a period of time, and can also be transmitted to the offspring [102]. Then, it can easily be hypothesized that epigenetic modifications correlate with SE processes [98]. In particular, the efficiency of cellular differentiation is linked to the methylation profile of DNA. The cellular reprogramming is often concomitant with significant changes in the chromatin status: not only DNA methylation but also histone modifications including methylation or acetylation [103,104]. Overall, DNA hypomethylation or histone acetylation are associated with transcriptional activation of regulatory genes that control development or hormone responses responsible for the totipotent state of the cells [39]. For example, in cotton, the level of CHH demethylation (one of the preferential DNA methylation contexts, with CG and CHG, where $\mathrm{H}$ can be an A, T or G) is a marker of somatic embryo differentiation [25]. By comparing SE recalcitrant vs. permissive genotypes, a hypermethylation of $\mathrm{CHH}$ is found, suggesting a repressive effect of methylation over SE-related genes expression, explaining why SE is less efficient for tissues with hypermethylated genomes [25]. Moreover, the DNA methylation level in callus decreases during embryogenesis and the important changes observed in the transcript levels during callus induction and somatic embryogenesis reflect the epigenetic reprogramming [39]. The use of deacetylation or demethylation inhibitors to promote the induction of somatic embryogenesis show that the chromatin profile of the tissue is a determining factor for SE induction, providing the evidence that chromatin regulations are directly involved in cell reprogramming and callus formation during SE [39,105-107].

POLYCOMB REPRESSIVE COMPLEXES (PRC) 1 and 2 are required for establishing and maintaining a stable epigenetic repression in response to developmental or environmental signals [108]. Briefly, PRC2 has a histone 3 lysine 27 trimethylation (H3K27me3) activity and PRC1 can recognize H3K27me3 and lead to chromatin compaction through histone H2A lysine ubiquitination (H2Aub) [49]. PCR2 is a main factor involved in cell identity to maintain a stable repression of embryogenesis program genes. PRC1 and PRC2 can repress the expression of several genes involved in cellular differentiation and callus development as well as somatic embryo formation including WOX5, WOX8, AGL15, LEC1, LEC2, ABI3, FUS3, BBM, PIN1 or PIN2 [109]. Consistent with these regulations, mutations 
in PRC2 subunits can lead to the formation of callus or abnormal development of vegetative tissues that resemble SE [110-112].

PICKLE genes (PKL and PIKLE RELATED 1 and $2-P K R 1$ and 2) are members of the CHD3 family of chromatin ATPases remodelers [113] and VAL1 and 2 (VIVIPAROUS/ABI3$L I K E)$ are transcriptional regulators containing DNA and chromatin binding domains [114]. Both PKL and VAL have a repressive effect on LAFL genes expression during zygotic embryo development [49,113-115]. In pkl and val1 mutants, the chromatin-based repression of LAFL is less important and consequently, the SE capacity is increased [52].

Mutations in genes involved in chromatin modifications, such as the DNA METHYLTRANSFERASE 1 (MET1) [116], KRYPTONITE (KYP) - an H2K9 METHYLTRANSFERASE [117], JUMONJI 14 (JMJ14) - an H3K4 DEMETHYLASE [118] and the HISTONE ACETYLTRANSFERASE 1 (HAC1) [119] lead to an alteration of WUS expression and a poorer formation of seedlings de novo after regeneration. Moreover, the functional analysis of met1 showed that DNA methylation and histone modification control de novo regeneration through WUS expression and auxin signaling [120].

Among chromatin-modification proteins involved in SE processes AHL15, an Arabidopsis AT-hook binding domain transcription factor that is important for chromatin opening, induces SE in absence of auxin treatment when it is overexpressed [121]. AHL15 and its homologs are positively regulated during hormone-mediated induction of SE and are required for the induction through BBM overexpression. AHL15 has a role in the level of heterochromatin in somatic cells: in loss-of-function mutants, the amount of heterochromatin is higher in in vitro culture and the capacity of cells to form somatic embryos after 2 , 4-D induction is altered.

miRNAs are also important during plant development because they target regulatory genes including transcription factors and F-box proteins [122,123]. DICER-LIKE 1 (DCL1), is a RNase III-like enzyme responsible for the biosynthesis of most plant miRNAs [124]. The dcl1 mutant, which is affected in the production of miRNAs, is not capable of inducing somatic embryogenesis [125]. This suggests that some miRNAs are crucial for SE induction processes, including auxin-related miRNAs that target genes of auxin perception, biosynthesis and signaling, for example: miR165/166, miR167, miR164, miR390 and miR393 [126].

In a recent study based on genome-wide analyses (ATAC-seq, ChIP-seq and RNA-seq), the authors observed a hierarchical organization of the transcriptional and chromatin mechanisms that regulate cellular reprogramming during plant somatic embryogenesis [127]. Their results suggest that the developmental stage of the explant used for tissue culture is at the top of the controlling hierarchy, as it determines the chromatin landscape. In fact, after germination, some specific chromatin permissive marks become inaccessible. This is the case for AP2, B3 and NF-Y genes that encode the key TFs inducing somatic embryogenesis. After the developmental stage of the explant, the second level of this hierarchical organization is auxins that induce important changes in chromatin accessibility and, consequently in genetic expression of specific genes, especially AP2 and B3 transcription factors. Finally, the third level of the hierarchy is composed of the transcription factors themselves (AP2, B3 and NF-Y), which are expressed thanks to their opened chromatin status, and that initiate or regulate embryo formation.

\section{Further Prospects}

The mechanisms underlying the control of somatic embryogenesis are multiple, involve complex gene regulatory networks, hormonal and epigenetic controls, and remain poorly understood. For instance, SOMATIC EMBRYOGENESIS RECEPTOR KINASE (SERK) genes are leucine-rich repeat receptor-like kinase (LRR-RKK) [128] first identified in carrot as markers of embryogenic cells and involved in the transition from the vegetative to embryogenic state of the cells, but also in response to environmental signals and in plant development [129]. In vitro, SERK expression can be induced by various stresses such as drought, wounding, or by altering hormone balance in the culture media [17]. 
From a gene regulatory network point of view, somatic embryogenesis shares similarities with zygotic embryogenesis, and some differences. The transcriptome of embryonic cells is similar to those of zygotic embryos at the octant stage, but not earlier [21,130], and many stress-related genes are also detected in somatic embryos [131]. This emphasizes the similarity of molecular controls involved but also some specificities. Moreover, the similarity may result from a convergence of different morphogenic pathways [21]. The production of embryogenic cells in Arabidopsis callus needs the repression of biochemical pathways and root meristem genes, while activating gene networks involved in shoot patterning and polarized cell growth rather than inducing specific zygotic embryo networks [21].

It can be hypothesized that SE is controlled by embryogenic genes that acquired different or more specialized functions (neo- or sub-functionalization) or specific regulations during evolution that remain under specific environmental or physiological conditions capable of inducing embryogenesis. Different master regulatory genes of zygotic embryogenesis, such as $L A F L$, can be involved in the cellular stress necessary for transcriptional reprogramming. Moreover, the AP2 family of transcription factors, which contains AINTEGUMENTA-LIKE (ANT), BABY BOOM (BBM) and PLETHORA (APB), is involved in the maintenance of sporophytic meristems in Angiosperms [132]. Nevertheless, in ferns these genes are involved in the establishment of a gametophytic meristem without fertilization, and the overexpression of ANT or the Brassica napus BBM gene significantly increases the formation of sporophytes without gamete (apogamy), whereas the knockdown of ANT reduces this ability [133]. This type of conservation of an ancestral function, also suggested for several transcription factors genes [132], can explain the ability of Angiosperms to produce somatic embryos.

The production of somatic embryos appears to be strongly linked to specific cellular events. For further comprehension of these mechanisms, a better understanding of the gene networks involved is necessary at the cellular level: characterization of single cell transcriptome, epigenome, and proteome are required to develop better knowledge about molecular events in place at the cellular level. Recent technologies of single cell analyses or cellular transcriptome atlas are thus highly important to better appreciate the early gene regulatory networks associated with somatic embryogenesis. These techniques applied to samples enriched in embryonic cells with the help of specific marker genes or specific morphological markers build the basis of a better knowledge on early controls of somatic embryogenesis. For example, the use of proLEC1 or proLEC2 fused to a fluorescent protein marker is considered as a valuable marker to detect early events of SE production as used in [21]. Similarly, to monitor early molecular changes during SE, using proBBM should certainly be considered [52,70].

LEC1 is acting as a pioneer TF during embryogenesis to control FLC expression [134]. LEC2 forming some complexes with LEC1 can be involved in similar regulations. This pioneer activity may induce the key genes involved in the reprogramming of a cell to form a somatic embryo (Figure 3). Nevertheless, TFs such as LEC2, ABI3 or FUS3, which have several protein domains, can perform different roles (i.e., controlling early embryogenesis, reserve accumulation or desiccation tolerance), depending on their partners in different cellular environments (Figures 2 and 3). Alternatively, the different functions can be linked if the ectopic triggering of the maturation processes induces stress in vegetative tissues leading to the initiation of somatic embryogenesis. 


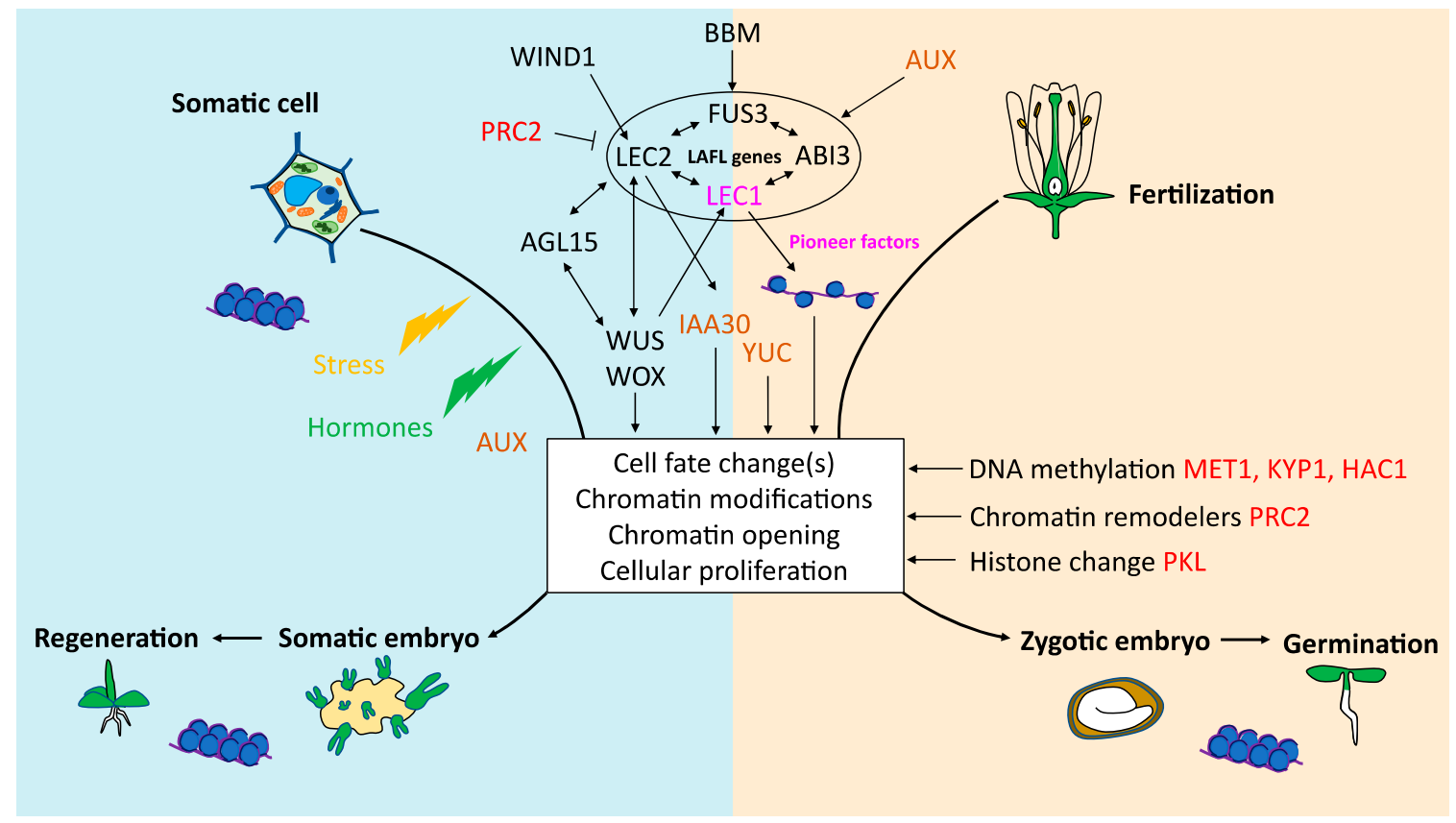

Figure 3. General overview of genes involved in somatic embryogenesis or zygotic embryogenesis in interaction with LEC1, ABI3, FUS3, and LEC2 (LAFL) transcription factors. Hormone-related genes are represented in brown, epigenetic regulators in red, transcription factors in black and pioneer factors in bright pink.

Author Contributions: Writing—review and editing, C.S., L.L., B.D. All authors have read and agreed to the published version of the manuscript.

Funding: This work has benefited from a French State grant (Saclay Plant Sciences, reference ANR-17EUR-0007, EUR SPS-GSR) managed by the French National Research Agency under an Investments for the Future program (reference ANR-11-IDEX-0003-02).

Institutional Review Board Statement: Not applicable.

Informed Consent Statement: Not applicable.

Data Availability Statement: Not applicable.

Acknowledgments: The authors thank M.M., S.K., H.W. and J.T. for critical reading of the manuscript.

Conflicts of Interest: The authors declare no conflict of interest. The funders had no role in the design of the study; in the collection, analyses, or interpretation of data; in the writing of the manuscript, or in the decision to publish the results.

\section{Abbreviations}

$\begin{array}{ll}\text { ABA } & \text { Abscisic Acid } \\ \text { ABI3 } & \text { ABSCISIC ACID INSENSITIVE 3 } \\ \text { AGL } & \text { AGAMOUS-LIKE } \\ \text { BBM } & \text { BABY BOOM } \\ \text { FUS3 } & \text { FUSCA 3 } \\ \text { GA } & \text { Gibberellic Acid } \\ \text { HAC1 } & \text { HISTONE ACETYLTRANSFERASE 1 } \\ \text { IAA30 } & \text { INDOL-3-ACETIC ACID INDUCIBLE 30 } \\ \text { KYP1 } & \text { KRYPTONITE 1 } \\ \text { LEC1 } & \text { LEAFY COTYLEDON 1 } \\ \text { LEC2 } & \text { LEAFY COTYLEDON 2 }\end{array}$




$\begin{array}{ll}\text { MET1 } & \text { METHYLTRANSFERASE 1 } \\ \text { PGR } & \text { Plant Growth Regulators } \\ \text { PKL } & \text { PICKLE } \\ \text { PRC2 } & \text { POLYCOMB RESPONSE COMPLEX 2 } \\ \text { SE } & \text { Somatic Embryogenesis } \\ \text { WUS } & \text { WUSCHEL } \\ \text { ZE } & \text { Zygotic Embryogenesis }\end{array}$

\section{References}

1. Jo, L.; Pelletier, J.M.; Harada, J.J. Central role of the LEAFY COTYLEDON1 transcription factor in seed development. J. Integr. Plant Biol. 2019, 61, 12806. [CrossRef]

2. Iluz, D. Zoochory: The dispersal of plants by animals. In All Flesh Is Grass; Dubinsky, Z., Seckbach, J., Eds.; Springer Netherlands: Dordrecht, The Netherlands, 2011; pp. 199-214, ISBN 978-90-481-9316-5.

3. Figueiredo, D.D.; Köhler, C. Auxin: A molecular trigger of seed development. Genes Dev. 2018, 32, 479-490. [CrossRef] [PubMed]

4. Garcês, H.M.P.; Champagne, C.E.M.; Townsley, B.T.; Park, S.; Malhó, R.; Pedroso, M.C.; Harada, J.J.; Sinha, N.R. Evolution of asexual reproduction in leaves of the genus Kalanchoë. Proc. Natl. Acad. Sci. USA 2007, 104, 15578-15583. [CrossRef] [PubMed]

5. Garcês, H.M.P.; Koenig, D.; Townsley, B.T.; Kim, M.; Sinha, N.R. Truncation of LEAFY COTYLEDON1 protein is required for asexual reproduction in Kalanchoë daigremontiana. Plant Physiol. 2014, 165, 196-206. [CrossRef] [PubMed]

6. $\quad$ Loyola-Vargas, V.M.; Avilez-Montalvo, J.R.; Avilés-Montalvo, R.N.; Márquez-López, R.E.; Galaz-Ávalos, R.M.; Mellado-Mojica, E. Somatic embryogenesis in Coffea spp. In Somatic Embryogenesis: Fundamental Aspects and Applications; Springer International Publishing: Cham, Switzerland, 2016; pp. 241-266, ISBN 9783319337050.

7. Lelu-Walter, M.-A.; Klimaszewska, K.; Miguel, C.; Aronen, T.; Hargreaves, C.; Teyssier, C.; Trontin, J.-F. Somatic embryogenesis for more effective breeding and deployment of improved varieties in Pinus spp.: Bottlenecks and recent advances. In Somatic Embryogenesis: Fundamental Aspects and Applications; Loyola-Vargas, V.M., Ochoa-Alejo, N., Eds.; Springer International Publishing: Cham, Switzerland, 2016; pp. 319-365, ISBN 9783319337050.

8. Alexandra Pila Quinga, L.; Heringer, A.S.; Pacheco de Freitas Fraga, H.; do Nascimento Vieira, L.; Silveira, V.; Steinmacher, D.A.; Guerra, M.P. Insights into the conversion potential of Theobroma cacao L. somatic embryos using quantitative proteomic analysis. Sci. Hortic. 2018, 229, 65-76. [CrossRef]

9. Loyola-Vargas, V.M.; Ochoa-Alejo, N. PartII Somatic Embryogenesis of Basic Models and Industrial and Agronomical Crops. In Somatic Embryogenesis: Fundamental Aspects and Applications; Loyola-Vargas, V.M., Ochoa-Alejo, N., Eds.; Springer International Publishing: Cham, Switzerland, 2016; pp. 185-412, ISBN 9783319337050.

10. Ochoa-Alejo, N. The uses of somatic embryogenesis for genetic transformation. In Somatic Embryogenesis: Fundamental Aspects and Applications; Loyola-Vargas, V.M., Ochoa-Alejo, N., Eds.; Springer International Publishing: Cham, Switzerland, 2016; pp. 415-434, ISBN 978-3-319-33705-0.

11. Rasmussen, S.K.; Kumar Mall, T.; Duraialagaraja, S.; Agrawal, P.K.; Yadava, P.; Abhishek, A.; Singh, R.; Singh, I.; Kaul, T.; Pattanayak, A. Advances in maize transformation technologies and development of transgenic maize. Front. Plant Sci. 2017, 7, 1949. [CrossRef]

12. Raza, G.; Singh, M.B.; Bhalla, P.L. Somatic embryogenesis and plant regeneration from commercial soybean cultivars. Plants 2020, 9, 38. [CrossRef]

13. Etienne, H.; Guyot, R.; Beulé, T.; Breitler, J.-C.; Jaligot, E. Plant fidelity in somatic embryogenesis-regenerated plants. In Somatic Embryogenesis: Fundamental Aspects and Applications; Loyola-Vargas, V.M., Ochoa-Alejo, N., Eds.; Springer International Publishing: Cham, Switzerland, 2016; pp. 121-150, ISBN 9783319337050.

14. Leljak-Levanić, D.; Mihaljević, S.; Bauer, N. Somatic and zygotic embryos share common developmental features at the onset of plant embryogenesis. Acta Physiol. Plant. 2015, 37, 1-14. [CrossRef]

15. Fehér, A. Somatic embryogenesis—stress-induced remodeling of plant cell fate. Biochim. Biophys. Acta Gene Regul. Mech. 2015, 1849, 385-402. [CrossRef]

16. Su, Y.H.; Tang, L.P.; Zhao, X.Y.; Zhang, X.S. Plant cell totipotency: Insights into cellular reprogramming. J. Integr. Plant Biol. 2020, 63, 228-243. [CrossRef]

17. Nic-Can, G.I.; Avilez-Montalvo, J.R.; Aviles-Montalvo, R.N.; Márquez-López, R.E.; Mellado-Mojica, E.; Galaz-Ávalos, R.M.; Loyola-Vargas, V.M. The relationship between stress and somatic embryogenesis. In Somatic Embryogenesis: Fundamental Aspects and Applications; Springer International Publishing: Cham, Switzerland, 2016; pp. 151-170, ISBN 9783319337050.

18. Skoog, F.; Miller, C.O. Chemical regulation of growth and organ formation in plant tissues cultured in vitro. Symp. Soc. Exp. Biol. 1957, 11, 118-130. [PubMed]

19. Nic-Can, G.I.; Loyola-Vargas, V.M. The role of the auxins during somatic embryogenesis. In Somatic Embryogenesis: Fundamental Aspects and Applications; Loyola-Vargas, V.M., Ochoa-Alejo, N., Eds.; Springer International Publishing: Cham, Switzerland, 2016; pp. 171-182, ISBN 9783319337050.

20. Nowak, K.; Gaj, M.D. Transcription factors in the regulation of somatic embryogenesis. In Somatic Embryogenesis: Fundamental Aspects and Applications; Springer International Publishing: Cham, Switzerland, 2016; pp. 53-79, ISBN 9783319337050. 
21. Magnani, E.; Jiménez-Gómez, J.M.; Soubigou-Taconnat, L.; Lepiniec, L.; Fiume, E. Profiling the onset of somatic embryogenesis in Arabidopsis. BMC Genom. 2017, 18, 1-12. [CrossRef] [PubMed]

22. Ikeda-Iwai, M.; Satoh, S.; Kamada, H. Establishment of a reproducible tissue culture system for the induction of Arabidopsis somatic embryos. J. Exp. Bot. 2002, 53, 1575-1580. [CrossRef] [PubMed]

23. Tian, R.; Paul, P.; Joshi, S.; Perry, S.E. Genetic activity during early plant embryogenesis. Biochem. J. 2020, $477,3743-3767$. [CrossRef] [PubMed]

24. Gaj, M.D. Factors influencing somatic embryogenesis induction and plant regeneration with particular reference to Arabidopsis thaliana (L.) Heynh. Plant Growth Regul. 2004, 43, 27-47. [CrossRef]

25. Guo, H.; Fan, Y.; Guo, H.; Wu, J.; Yu, X.; Wei, J.; Lian, X.; Zhang, L.; Gou, Z.; Fan, Y.; et al. Somatic embryogenesis critical initiation stage-specific $\mathrm{mCHH}$ hypomethylation reveals epigenetic basis underlying embryogenic redifferentiation in cotton. Plant Biotechnol. J. 2020, 1-3. [CrossRef]

26. Solís-Ramos, Y.L.; Andrade-Torres, A.; Sáenz Carbonell, L.A.; Oropeza Salín, C.M.; Castaño de la Ser, E. Somatic embryogenesis in recalcitrant plants. In Embryogenesis; Sato, K.-I., Ed.; InTech: Kyoto, Japan, 2012; pp. 597-618. [CrossRef]

27. Casanova-Sáez, R.; Voß, U. Auxin metabolism controls developmental decisions in land plants. Trends Plant Sci. 2019, 24, 741-754. [CrossRef] [PubMed]

28. Paque, S.; Weijers, D. Q\&A: Auxin: The plant molecule that influences almost anything. BMC Biol. 2016, 14, 67. [CrossRef]

29. Petrášek, J.; Friml, J. Auxin transport routes in plant development. Development 2009, 136, 2675-2688. [CrossRef]

30. Robert, H.S.; Grones, P.; Stepanova, A.N.; Robles, L.M.; Lokerse, A.S.; Alonso, J.M.; Weijers, D.; Friml, J. Local auxin sources orient the apical-basal axis in Arabidopsis embryos. Curr. Biol. 2013, 23, 2506-2512. [CrossRef] [PubMed]

31. Xiong, F.; Liu, H.H.; Duan, C.Y.; Zhang, B.K.; Wei, G.; Zhang, Y.; Li, S. Arabidopsis JANUS regulates embryonic pattern formation through Pol II-Mediated transcription of WOX2 and PIN7. iScience 2019, 19, 1179-1188. [CrossRef] [PubMed]

32. Robert, H.S.; Grunewald, W.; Sauer, M.; Cannoot, B.; Soriano, M.; Swarup, R.; Weijers, D.; Bennett, M.; Boutilier, K.; Friml, J. Plant embryogenesis requires AUX/LAX-mediated auxin influx. Development 2015, 142, 702-711. [CrossRef] [PubMed]

33. Wójcik, A.M.; Wójcikowska, B.; Gaj, M.D. Current perspectives on the auxin-mediated genetic network that controls the induction of somatic embryogenesis in plants. Int. J. Mol. Sci. 2020, 21, 1333. [CrossRef]

34. Márquez-López, R.E.; Pérez-Hernández, C.; Ku-González, Á.; Galaz-Ávalos, R.M.; Loyola-Vargas, V.M. Localization and transport of indole-3-acetic acid during somatic embryogenesis in Coffea canephora. Protoplasma 2018, 255, 695-708. [CrossRef] [PubMed]

35. Wójcikowska, B.; Gaj, M.D. Expression profiling of AUXIN RESPONSE FACTOR genes during somatic embryogenesis induction in Arabidopsis. Plant Cell Rep. 2017, 36, 843-858. [CrossRef]

36. Zheng, Y.; Ren, N.; Wang, H.; Stromberg, A.J.; Perry, S.E. Global identification of targets of the Arabidopsis MADS domain protein AGAMOUS-Like15. Plant Cell 2009, 21, 2563-2577. [CrossRef]

37. Wójcikowska, B.; Jaskóła, K.; Gąsiorek, P.; Meus, M.; Nowak, K.; Gaj, M.D. LEAFY COTYLEDON2 (LEC2) promotes embryogenic induction in somatic tissues of Arabidopsis, via YUCCA-mediated auxin biosynthesis. Planta 2013, 238, 425-440. [CrossRef]

38. Pasternak, T.; Miskolczi, P.; Ayaydin, F.; Mészáros, T.; Dudits, D.; Fehér, A. Exogenous auxin and cytokinin dependent activation of CDKs and cell division in leaf protoplast-derived cells of alfalfa. Plant Growth Regul. 2000, 32, 129-141. [CrossRef]

39. Pasternak, T.; Dudits, D. Epigenetic clues to better understanding of the asexual embryogenesis in planta and in vitro. Front. Plant Sci. 2019, 10, 1-5. [CrossRef] [PubMed]

40. Horstman, A.; Bemer, M.; Boutilier, K. A transcriptional view on somatic embryogenesis. Regeneration 2017, 4, 201-216. [CrossRef] [PubMed]

41. Santos Mendoza, M.; Dubreucq, B.; Miquel, M.; Caboche, M.; Lepiniec, L. LEAFY COTYLEDON 2 activation is sufficient to trigger the accumulation of oil and seed specific mRNAs in Arabidopsis leaves. FEBS Lett. 2005, 579, 4666-4670. [CrossRef] [PubMed]

42. Braybrook, S.A.; Harada, J.J. LECs go crazy in embryo development. Trends Plant Sci. 2008, 13, 624-630. [CrossRef] [PubMed]

43. Carbonero, P.; Iglesias-Fernández, R.; Vicente-Carbajosa, J. The AFL subfamily of B3 transcription factors: Evolution and function in angiosperm seeds. J. Exp. Bot. 2017, 68, 871-880. [CrossRef] [PubMed]

44. Sasnauskas, G.; Kauneckaite, K.; Siksnys, V. Structural basis of DNA target recognition by the B3 domain of Arabidopsis epigenome reader VAL1. Nucleic Acids Res. 2018, 46, 4316-4324. [CrossRef] [PubMed]

45. Baumlein, H.; Villarroel, R.; Inz, D.; Wobus, U. Cis-analysis of a seed protein gene promoter: The conservative $R Y$ repeat CATGCATG within the legumin box is essential for tissue-specific expression of a legumin gene. Plant J. 1991, 2, $233-239$.

46. Baud, S.; Kelemen, Z.; Thévenin, J.; Boulard, C.; Blanchet, S.; To, A.; Payre, M.; Berger, N.; Effroy-Cuzzi, D.; Franco-Zorrilla, J.M.; et al. Deciphering the molecular mechanisms underpinning the transcriptional control of gene expression by master transcriptional regulators in Arabidopsis seed. Plant Physiol. 2016, 171, 1099-1112. [CrossRef]

47. Lee, H.; Fischer, R.L.; Goldberg, R.B.; Harada, J.J. Arabidopsis LEAFY COTYLEDON1 represents a functionally specialized subunit of the CCAAT binding transcription factor. Proc. Natl. Acad. Sci. USA 2003, 100, 2152-2156. [CrossRef]

48. Santos-Mendoza, M.; Dubreucq, B.; Bastien Baud, S.; Parcy, F.; Caboche, M.; Lepiniec, L. Deciphering gene regulatory networks that control seed development and maturation in Arabidopsis. Plant J. 2008, 54, 608-620. [CrossRef] [PubMed]

49. Lepiniec, L.; Devic, M.; Roscoe, T.J.; Bouyer, D.; Zhou, D.X.; Boulard, C.; Baud, S.; Dubreucq, B. Molecular and epigenetic regulations and functions of the LAFL transcriptional regulators that control seed development. Plant Reprod. 2018, 31, 291-307. [CrossRef] 
50. Kumar, V.; Jha, P.; Van Staden, J. LEAFY COTYLEDONs (LECs): Master regulators in plant embryo development. Plant Cell. Tissue Organ Cult. 2020, 140, 475-487. [CrossRef]

51. Boulard, C.; Fatihi, A.; Lepiniec, L.; Dubreucq, B. Regulation and evolution of the interaction of the seed B3 transcription factors with NF-Y subunits. Biochim. Biophys. Acta Gene Regul. Mech. 2017, 1860, 1069-1078. [CrossRef]

52. Horstman, A.; Li, M.; Heidmann, I.; Weemen, M.; Chen, B.; Muiño, J.M.; Angenent, G.C.; Boutilier, K.; Muino, J.M.; Angenent, G.C.; et al. The BABY BOOM transcription factor activates the LEC1-ABI3-FUS3-LEC2 network to induce somatic embryogenesis. Plant Physiol. 2017, 175, 848-857. [CrossRef]

53. Ledwoń, A.; Gaj, M.D. LEAFY COTYLEDON1, FUSCA3 expression and auxin treatment in relation to somatic embryogenesis induction in Arabidopsis. Plant Growth Regul. 2011, 65, 157-167. [CrossRef]

54. Gaj, M.D.; Zhang, S.; Harada, J.J.; Lemaux, P.G. Leafy cotyledon genes are essential for induction of somatic embryogenesis of Arabidopsis. Planta 2005, 222, 977-988. [CrossRef]

55. Stone, S.L.; Kwong, L.W.; Yee, K.M.; Pelletier, J.; Lepiniec, L.; Fischer, R.L.; Goldberg, R.B.; Harada, J.J. LEAFY COTYLEDON2 encodes a B3 domain transcription factor that induces embryo development. Proc. Natl. Acad. Sci. USA 2001, 98, 11806-11811. [CrossRef]

56. Feeney, M.; Frigerio, L.; Cui, Y.; Menassa, R. Following vegetative to embryonic cellular changes in leaves of Arabidopsis overexpressing LEAFY COTYLEDON2. Plant Physiol. 2013, 162, 1881-1896. [CrossRef]

57. Lotan, T.; Ohto, M.A.; Matsudaira Yee, K.; West, M.A.L.; Lo, R.; Kwong, R.W.; Yamagishi, K.; Fischer, R.L.; Goldberg, R.B.; Harada, J.J. Arabidopsis LEAFY COTYLEDON1 is sufficient to induce embryo development in vegetative cells. Cell 1998, 93, 1195-1205. [CrossRef]

58. Liu, Z.; Ge, X.X.; Qiu, W.M.; Long, J.M.; Jia, H.H.; Yang, W.; Dutt, M.; Wu, X.M.; Guo, W.W. Overexpression of the CsFUS3 gene encoding a B3 transcription factor promotes somatic embryogenesis in Citrus. Plant Sci. 2018, 277, 121-131. [CrossRef] [PubMed]

59. Guo, F.; Liu, C.; Xia, H.; Bi, Y.; Zhao, C.; Zhao, S.; Hou, L.; Li, F.; Wang, X. Induced expression of AtLEC1 and AtLEC2 differentially promotes somatic embryogenesis in transgenic tobacco plants. PLoS ONE 2013, 8, e71714. [CrossRef]

60. Zheng, W.; Zhang, X.; Yang, Z.; Wu, J.; Li, F.; Duan, L.; Liu, C.; Lu, L.; Zhang, C.; Li, F. AtWUSCHEL promotes formation of the embryogenic callus in Gossypium hirsutum. PLoS ONE 2014, 9, e87502. [CrossRef] [PubMed]

61. Braybrook, S.A.; Stone, S.L.; Park, S.; Bui, A.Q.; Le, B.H.; Fischer, R.L.; Goldberg, R.B.; Harada, J.J. Genes directly regulated by LEAFY COTYLEDON2 provide insight into the control of embryo maturation and somatic embryogenesis. Proc. Natl. Acad. Sci. USA 2006, 103, 3468-3473. [CrossRef]

62. Zheng, Q.; Zheng, Y.; Ji, H.; Burnie, W.; Perry, S.E. Gene regulation by the AGL15 transcription factor reveals hormone interactions in somatic embryogenesis. Plant Physiol. 2016, 172, 2374-2387. [CrossRef]

63. Sato, A.; Yamamoto, K.T. Overexpression of the non-canonical Aux/IAA genes causes auxin-related aberrant phenotypes in Arabidopsis. Physiol. Plant. 2008, 133, 397-405. [CrossRef]

64. Xu, C.; Luo, F.; Hochholdinger, F. LOB domain proteins: Beyond lateral organ boundaries. Trends Plant Sci. 2016, 21, 159-167. [CrossRef]

65. Stone, S.L.; Braybrook, S.A.; Paula, S.L.; Kwong, L.W.; Meuser, J.; Pelletier, J.; Hsieh, T.-F.; Fischer, R.L.; Goldberg, R.B.; Harada, J.J. Arabidopsis LEAFY COTYLEDON2 induces maturation traits and auxin activity: Implications for somatic embryogenesis. Proc. Natl. Acad. Sci. USA 2008, 105, 3151-3156. [CrossRef] [PubMed]

66. To, A.; Valon, C.; Savino, G.; Guilleminot, J.; Devic, M.; Giraudat, J.; Parcy, F. A network of local and redundant gene regulation governs Arabidopsis seed maturation. Plant Cell Online 2006, 18, 1642-1651. [CrossRef] [PubMed]

67. Sengupta, S.; Nag Chaudhuri, R. ABI3 plays a role in de-novo root regeneration from Arabidopsis thaliana callus cells. Plant Signal. Behav. 2020, 15, 1794147. [CrossRef] [PubMed]

68. Parcy, F.; Valon, C.; Raynal, M.; Gaubier-Comella, P.; Delseny, M.; Giraudat, J. Regulation of gene expression programs during Arabidopsis seed development: Roles of the ABI3 locus and of endogenous abscisic acid. Plant Cell 1994, 6, 1567-1582. [CrossRef]

69. Parcy, F.; Giraudat, J. Interactions between the $A B I 1$ and the ectopically expressed $A B I 3$ genes in controlling abscisic acid responses in Arabidopsis vegetative tissues. Plant J. 1997, 11, 693-702. [CrossRef]

70. Boutilier, K.; Offringa, R.; Sharma, V.K.; Kieft, H.; Ouellet, T.; Zhang, L.; Hattori, J.; Liu, C.-M.; van Lammeren, A.A.M.; Miki, B.L.A.; et al. Ectopic expression of BABY-BOOM triggers a conversion from vegetative to embryonic growth. Plant Cell 2002, 14, 1737-1749. [CrossRef]

71. Riechmann, J.L.; Meyerowitz, E.M. The AP2/EREBP family of plant transcription factors. Biol. Chem. 1998, 379, 633-646. [CrossRef]

72. Mizoi, J.; Shinozaki, K.; Yamaguchi-Shinozaki, K. AP2/ERF family transcription factors in plant abiotic stress responses. Biochim. Biophys. Acta Gene Regul. Mech. 2012, 1819, 86-96. [CrossRef]

73. Galinha, C.; Hofhuis, H.; Luijten, M.; Willemsen, V.; Blilou, I.; Heidstra, R.; Scheres, B. PLETHORA proteins as dose-dependent master regulators of Arabidopsis root development. Nature 2007, 449, 1053-1057. [CrossRef]

74. Laux, T.; Mayer, K.F.X.; Berger, J.; Jürgens, G. The WUSCHEL gene is required for shoot and floral meristem integrity in Arabidopsis. Development 1996, 122, 87-96. [CrossRef]

75. Zuo, J.; Niu, Q.W.; Frugis, G.; Chua, N.H. The WUSCHEL gene promotes vegetative-to-embryonic transition in Arabidopsis. Plant J. 2002, 30, 349-359. [CrossRef] [PubMed] 
76. Jha, P.; Ochatt, S.J.; Kumar, V. WUSCHEL: A master regulator in plant growth signaling. Plant Cell Rep. 2020, 39, 431-444. [CrossRef] [PubMed]

77. Mordhorst, A.P.; Hartog, M.V.; El Tamer, M.K.; Laux, T.; De Vries, S.C. Somatic embryogenesis from Arabidopsis shoot apical meristem mutants. Planta 2002, 214, 829-836. [CrossRef]

78. Bouchabké-Coussa, O.; Obellianne, M.; Linderme, D.; Montes, E.; Maia-Grondard, A.; Vilaine, F.; Pannetier, C. WUSCHEL overexpression promotes somatic embryogenesis and induces organogenesis in cotton (Gossypium hirsutum L.) tissues cultured in vitro. Plant Cell Rep. 2013, 32, 675-686. [CrossRef] [PubMed]

79. Arroyo-Herrera, A.; Ku Gonzalez, A.; Canche Moo, R.; Quiroz-Figueroa, F.R.; Loyola-Vargas, V.M.; Rodriguez-Zapata, L.C.; Burgeff D'Hondt, C.; Suárez-Solís, V.M.; Castaño, E. Expression of WUSCHEL in Coffea canephora causes ectopic morphogenesis and increases somatic embryogenesis. Plant Cell. Tissue Organ Cult. 2008, 94, 171-180. [CrossRef]

80. Orłowska, A.; Kepczyńska, E. Identification of Polycomb Repressive Complex1, Trithorax group genes and their simultaneous expression with WUSCHEL, WUSCHEL-related Homeobox 5 and SHOOT MERISTEMLESS during the induction phase of somatic embryogenesis in Medicago truncatula Gaertn. Plant Cell. Tissue Organ Cult. 2018, 134, 345-356. [CrossRef]

81. Haecker, A.; Groß-Hardt, R.; Geiges, B.; Sarkar, A.; Breuninger, H.; Herrmann, M.; Laux, T. Expression dynamics of WOX genes mark cell fate decisions during early embryonic patterning in Arabidopsis thaliana. Development 2004, 131, 657-668. [CrossRef] [PubMed]

82. Tvorogova, V.E.; Fedorova, Y.A.; Potsenkovskaya, E.A.; Kudriashov, A.A.; Efremova, E.P.; Kvitkovskaya, V.A.; Wolabu, T.W.; Zhang, F.; Tadege, M.; Lutova, L.A. The WUSCHEL-related homeobox transcription factor MtWOX9-1 stimulates somatic embryogenesis in Medicago truncatula. Plant Cell. Tissue Organ Cult. 2019, 138, 517-527. [CrossRef]

83. Masiero, S.; Colombo, L.; Grini, P.E.; Schnittger, A.; Kater, M.M. The emerging importance of type I MADS box transcription factors for plant reproduction. Plant Cell 2011, 23, 865-872. [CrossRef]

84. Heck, G.R.; Perry, S.E.; Nichols, K.W.; Fernandez, D.E. AGL15, a MADS domain protein expressed in developing embryos. Plant Cell 1995, 7, 1271-1282. [CrossRef] [PubMed]

85. Rounsley, S.D.; Ditta, G.S.; Yanofsky, M.F. Diverse roles for MADS box genes in Arabidopsis development. Plant Cell 1995, 7, 1259-1269. [CrossRef] [PubMed]

86. Wang, H.; Caruso, L.V.; Downie, A.B.; Perry, S.E. The embryo MADS domain protein AGAMOUS-LIKE15 directly regulates expression of a gene encoding an enzyme involved in gibberellin metabolism. Plant Cell 2004, 16, 1206-1219. [CrossRef]

87. Zhu, C.; Perry, S.E. Control of expression and autoregulation of AGL15, a member of the MADS-box family. Plant J. 2005, 41, 583-594. [CrossRef]

88. Harding, E.W.; Tang, W.; Nichols, K.W.; Fernandez, D.E.; Perry, S.E. Expression and maintenance of embryogenic potential is enhanced through constitutive expression of AGAMOUS-LIKE15. Plant Physiol. 2003, 133, 653-663. [CrossRef]

89. Thakare, D.; Tang, W.; Hill, K.; Perry, S.E. The MADS-domain transcriptional regulator AGAMOUS-Like15 promotes somatic embryo development in Arabidopsis and soybean. Plant Physiol. 2008, 146, 1663-1672. [CrossRef]

90. Iwase, A.; Ishii, H.; Aoyagi, H.; Ohme-Takagi, M.; Tanaka, H. Comparative analyses of the gene expression profiles of Arabidopsis intact plant and cultured cells. Biotechnol. Lett. 2005, 27, 1097-1103. [CrossRef]

91. Iwase, A.; Mitsuda, N.; Koyama, T.; Hiratsu, K.; Kojima, M.; Arai, T.; Inoue, Y.; Seki, M.; Sakakibara, H.; Sugimoto, K.; et al. The AP2/ERF transcription factor WIND1 controls cell dedifferentiation in Arabidopsis. Curr. Biol. 2011, 21, 508-514. [CrossRef] [PubMed]

92. Iwase, A.; Mita, K.; Nonaka, S.; Ikeuchi, M.; Koizuka, C.; Ohnuma, M.; Ezura, H.; Imamura, J.; Sugimoto, K. WIND1-based acquisition of regeneration competency in Arabidopsis and rapeseed. J. Plant Res. 2015, 128, 389-397. [CrossRef] [PubMed]

93. Iwafuchi-Doi, M. The mechanistic basis for chromatin regulation by pioneer transcription factors. Wiley Interdiscip. Rev. Syst. Biol. Med. 2019, 11, e1427. [CrossRef]

94. Zaret, K.S.; Carroll, J.S. Pioneer transcription factors: Establishing competence for gene expression. Genes Dev. 2011, 25, $2227-2241$. [CrossRef]

95. Mayran, A.; Drouin, J. Pioneer transcription factors shape the epigenetic landscape. J. Biol. Chem. 2018, 293, 13795-13804. [CrossRef]

96. Zaret, K.S. Pioneering the chromatin landscape. Nat. Genet. 2018, 50, 167-169. [CrossRef]

97. Tao, Z.; Hu, H.; Luo, X.; Jia, B.; Du, J.; He, Y. Embryonic resetting of the parental vernalized state by two B3 domain transcription factors in Arabidopsis. Nat. Plants 2019, 5, 424-435. [CrossRef] [PubMed]

98. Kumar, V.; Van Staden, J. New insights into plant somatic embryogenesis: An epigenetic view. Acta Physiol. Plant. 2017, 39, 1-17. [CrossRef]

99. Klemm, S.L.; Shipony, Z.; Greenleaf, W.J. Chromatin accessibility and the regulatory epigenome. Nat. Rev. Genet. 2019, 20, 207-220. [CrossRef]

100. Peng, H.; Zhang, J. Plant genomic DNA methylation in response to stresses: Potential applications and challenges in plant breeding. Prog. Nat. Sci. 2009, 19, 1037-1045. [CrossRef]

101. Akhter, Z.; Bi, Z.; Ali, K.; Sun, C.; Fiaz, S.; Haider, F.U.; Bai, J. In response to abiotic stress, DNA methylation confers epigenetic changes in plants. Plants 2021, 10, 1096. [CrossRef]

102. Liu, J.; He, Z. Small DNA Methylation, big player in plant abiotic stress responses and memory. Front. Plant Sci. 2020, 11, 1977. [CrossRef] 
103. Lee, K.; Seo, P.J. Dynamic epigenetic changes during plant regeneration. Trends Plant Sci. 2018, 23, 235-247. [CrossRef] [PubMed]

104. Birnbaum, K.D.; Roudier, F. Epigenetic memory and cell fate reprogramming in plants. Regeneration 2017, 4, 15-20. [CrossRef] [PubMed]

105. Lee, K.; Park, O.S.; Jung, S.J.; Seo, P.J. Histone deacetylation-mediated cellular dedifferentiation in Arabidopsis. J. Plant Physiol. 2016, 191, 95-100. [CrossRef]

106. Li, J.; Wang, M.; Li, Y.; Zhang, Q.; Lindsey, K.; Daniell, H.; Jin, S.; Zhang, X. Multi-omics analyses reveal epigenomics basis for cotton somatic embryogenesis through successive regeneration acclimation process. Plant Biotechnol. J. 2019, 17, 435-450. [CrossRef]

107. Osorio-Montalvo, P.; Sáenz-Carbonell, L.; De-la-Peña, C. 5-Azacytidine: A Promoter of Epigenetic Changes in the Quest to Improve Plant Somatic Embryogenesis. Int. J. Mol. Sci. 2018, 19, 3182. [CrossRef]

108. Mozgova, I.; Hennig, L. The polycomb group protein regulatory network. Annu. Rev. Plant Biol. 2015, 66, 269-296. [CrossRef]

109. Duarte-Aké, F.; Nic-Can, G.; De-la-Peña, C. Somatic embryogenesis: Polycomb complexes control cell-to-embryo transition. In Epigenetics in Plants of Agronomic Importance: Fundamentals and Applications; Springer International Publishing: Cham, Switzerland, 2019; pp. 339-354, ISBN 9783030147600.

110. Ikeuchi, M.; Iwase, A.; Rymen, B.; Harashima, H.; Shibata, M.; Ohnuma, M.; Breuer, C.; Karina Morao, A.; de Lucas, M.; De Veylder, L.; et al. PRC2 represses dedifferentiation of mature somatic cells in Arabidopsis. Nat. Plants 2015, 1, 15089. [CrossRef] [PubMed]

111. Chanvivattana, Y.; Bishopp, A.; Schubert, D.; Stock, C.; Moon, Y.H.; Sung, Z.R.; Goodrich, J. Interaction of Polycomb-group proteins controlling flowering in Arabidopsis. Development 2004, 131, 5263-5276. [CrossRef]

112. Mozgová, I.; Muñoz-Viana, R.; Hennig, L. PRC2 represses hormone-induced somatic embryogenesis in vegetative tissue of Arabidopsis thaliana. PLoS Genet. 2017, 13, e1006562. [CrossRef]

113. Han, S.K.; Wu, M.F.; Cui, S.; Wagner, D. Roles and activities of chromatin remodeling ATPases in plants. Plant J. 2015, 83, 62-77. [CrossRef]

114. Schneider, A.; Aghamirzaie, D.; Elmarakeby, H.; Poudel, A.N.; Koo, A.J.; Heath, L.S.; Grene, R.; Collakova, E. Potential targets of VIVIPAROUS1/ABI3-LIKE1 (VAL1) repression in developing Arabidopsis thaliana embryos. Plant J. 2016, 85, 305-319. [CrossRef] [PubMed]

115. Shen, Y.; Devic, M.; Lepiniec, L.; Zhou, D.X. Chromodomain, Helicase and DNA-binding CHD1 protein, CHR5, are involved in establishing active chromatin state of seed maturation genes. Plant Biotechnol. J. 2015, 13, 811-820. [CrossRef] [PubMed]

116. Brocklehurst, S.; Watson, M.; Carr, I.M.; Out, S.; Heidmann, I.; Meyer, P. Induction of epigenetic variation in Arabidopsis by over-expression of DNA METHYLTRANSFERASE1 (MET1). PLOS ONE 2018, 13, e0192170. [CrossRef]

117. Jackson, J.P.; Lindroth, A.M.; Cao, X.; Jacobsen, S.E. Control of CpNpG DNA methylation by the KRYPTONITE histone H3 methyltransferase. Nature 2002, 416, 556-560. [CrossRef] [PubMed]

118. Cattaneo, P.; Graeff, M.; Marhava, P.; Hardtke, C.S. Conditional effects of the epigenetic regulator JUMONJI 14 in Arabidopsis root growth. Development 2019, 146. [CrossRef] [PubMed]

119. Deng, W.; Liu, C.; Pei, Y.; Deng, X.; Niu, L.; Cao, X. Involvement of the Histone Acetyltransferase AtHAC1 in the Regulation of Flowering Time via Repression of FLOWERING LOCUS C in Arabidopsis. Plant Physiol. 2007, 143, 1660-1668. [CrossRef]

120. Li, W.; Liu, H.; Cheng, Z.J.; Su, Y.H.; Han, H.N.; Zhang, Y.; Zhang, X.S. DNA methylation and histone modifications regulate de novo shoot regeneration in Arabidopsis by modulating WUSCHEL expression and auxin signaling. PLoS Genet. 2011, 7, e1002243. [CrossRef] [PubMed]

121. Karami, O.; Rahimi, A.; Mak, P.; Horstman, A.; Boutilier, K.; Compier, M.; van der Zaal, B.; Offringa, R. An Arabidopsis AT-hook motif nuclear protein mediates somatic embryogenesis and coinciding genome duplication. Nat. Commun. 2021, 12. [CrossRef] [PubMed]

122. Jones-Rhoades, M.W.; Bartel, D.P.; Bartel, B. microRNAs and their regulatory roles in plants. Annu. Rev. Plant Biol. 2006, 57, 19-53. [CrossRef] [PubMed]

123. Bartel, D.P. MicroRNAs: Target recognition and regulatory functions. Cell 2009, 136, 215-233. [CrossRef]

124. Reinhart, B.J.; Weinstein, E.G.; Rhoades, M.W.; Bartel, B.; Bartel, D.P. MicroRNAs in plants. Genes Dev. 2002, 1616-1626. [CrossRef] [PubMed]

125. Wójcik, A.M.; Gaj, M.D. miR393 contributes to the embryogenic transition induced in vitro in Arabidopsis via the modification of the tissue sensitivity to auxin treatment. Planta 2016, 244. [CrossRef]

126. Wójcikowska, B.; Wójcik, A.M.; Gaj, M.D. Epigenetic regulation of auxin-induced somatic embryogenesis in plants. Int. J. Mol. Sci. 2020, 21, 2307. [CrossRef] [PubMed]

127. Wang, F.-X.; Shang, G.-D.; Wu, L.-Y.; Xu, G.-Z.; Zhao, X.-Y.; Wang, J.-W. Chromatin accessibility dynamics and a hierarchical transcriptional regulatory network structure for plant somatic embryogenesis. SSRN Electron. J. 2020, 1-16. [CrossRef]

128. Schmidt, E.D.L.; Guzzo, F.; Toonen, M.A.J.; De Vries, S.C. A leucine-rich repeat containing receptor-like kinase marks somatic plant cells competent to form embryos. Development 1997, 124, 2049-2062. [CrossRef]

129. Kumar, V.; Van Staden, J. Multi-tasking of SERK-like kinases in plant embryogenesis, growth, and development: Current advances and biotechnological applications. Acta Physiol. Plant. 2019, 41, 31. [CrossRef]

130. Hofmann, F.; Schon, M.A.; Nodine, M.D. The embryonic transcriptome of Arabidopsis thaliana. Plant Reprod. $2019,32,77-91$. [CrossRef] [PubMed] 
131. Jin, F.; Hu, L.; Yuan, D.; Xu, J.; Gao, W.; He, L.; Yang, X.; Zhang, X. Comparative transcriptome analysis between somatic embryos (SEs) and zygotic embryos in cotton: Evidence for stress response functions in SE development. Plant Biotechnol. J. 2014, 12, 161-173. [CrossRef]

132. Romani, F.; Moreno, J.E. Molecular mechanisms involved in functional macroevolution of plant transcription factors. New Phytol. 2020, 230, 1345-1353. [CrossRef] [PubMed]

133. Bui, L.T.; Pandzic, D.; Youngstrom, C.E.; Wallace, S.; Irish, E.E.; Szövényi, P.; Cheng, C.L. A fern AINTEGUMENTA gene mirrors $B A B Y$ BOOM in promoting apogamy in Ceratopteris richardii. Plant J. 2017, 90, 122-132. [CrossRef] [PubMed]

134. Tao, Z.; Shen, L.; Gu, X.; Wang, Y.; Yu, H.; He, Y. Embryonic epigenetic reprogramming by a pioneer transcription factor in plants. Nature 2017, 551, 124-128. [CrossRef] [PubMed] 